\title{
Art in science class vs science in art class: a Study in Elementary School
}

Britt Jakobson and Per-Olof Wickman

\section{(2) OpenEdition \\ 1 Journals}

\section{Electronic version}

URL: http://journals.openedition.org/educationdidactique/396

DOI: 10.4000/educationdidactique.396

ISBN: 978-2-7535-1619-9

ISSN: $2111-4838$

Publisher

Presses universitaires de Rennes

\section{Printed version}

Date of publication: 1 December 2008

Number of pages: 141-157

ISBN: 978-2-7535-0790-6

ISSN: $1956-3485$

\section{Electronic reference}

Britt Jakobson and Per-Olof Wickman, « Art in science class vs science in art class: a Study in Elementary School », Éducation et didactique [Online], 2-3 | Décembre 2008, Online since 01 December 2010, connection on 08 December 2020. URL : http://journals.openedition.org/educationdidactique/ 396 ; DOI : https://doi.org/10.4000/educationdidactique.396 


\title{
ART IN SCIENCE CLASS VS SCIENCE IN ART CLASS: A STUDY IN ELEMENTARY SCHOOL
}

\author{
Britt Jakobson \& Per-Olof Wickman, \\ Stockholm University
}

\begin{abstract}
Résumé : We examine how observations and art activities mediate what elementary school children learn in science. We compare results from six different settings in which the children were involved in observing and depicting fish with texts and illustrations using various resources. In three of the settings the aim was scientific, and in the remaining three artistic. The data has been analysed in the light of pragmatist theories and socio-cultural perspectives (a practical epistemology analysis). The results show that different resources afforded the children to observe certain qualities and disregard others. In both the science and art classes the children learned about aesthetics, which involved moral considerations. .
\end{abstract}

Key-words: elementary school, science, art, pragmatism, mediation

Britt Jakobson \& Per-Olof Wickman

\section{Introduction}

In this article we examine how observational and art activities may promote the learning of science in elementary school. We compare the results from six different settings in which the children were involved in observing (one setting) and observing and depicting fish with texts and illustrations (five settings) and using a variety of resources. In three of the settings the aim was scientific, and in the remaining three artistic. Our main research question centres on what these different activities afforded children to learn about the qualities of fish. The children were also aesthetically involved when observing and depicting the fish; something that became apparent in their use of aesthetic judgements with regard to what they found pleasing/displeasing and beautiful/ ugly (Wickman, 2006). We discuss what this means for the direction that learning takes.

Art in science education is traditionally viewed as subjective and emotional in contrast to science, which is regarded as an objective and cognitive enterprise (e.g. Gardner, 1971; Strike \& Posner, 1992). However, several scholars have drawn attention to the fact that art bears a close resemblance to science, meaning that values and emotions are not only embedded in art, but also in science and in the science classroom, and are important aspects to take into account when considering the direction that learning takes (e.g. Bloom, 1992a, b; Jakobson \& Wickman 2008; Wickman, 2006). This is contrary to the ideas of some researchers who approach emotions merely as a motivational drive or a question of attitudes (e.g. Novak, 2002; Posner, Strike, Hewson, \& Gertzog, 1982; Strike \& Posner, 1992). Goodman (1969) maintains that the difference between art and science is simply a matter of the symbols used, and that both activities are cognitive. In line with this, many scholars emphasise that science and art should not be viewed as different enterprises, but as being compatible (e.g. Fischer, 1999; Root-Bernstein, 1991, 1996; Watts, 2001; Weisskopf, 1979; Vickers, 1988).

Although many scholars emphasise the significance of art in science education a few empirical studies relate to the use of art activities in the science classroom. Weigand (1985) examined the role of art in high school science and concludes that scientific and artistic modes of inquiry enhance and balance each other; something that is also argued by Laverne Nelson, Martin and Baldwin (1998). Moreover, some empirical studies show that art activities enhance children's observation skills (e.g. Gainer \& Child, 1986; Hayes, Symington, \& Martin, 1994; Laverne Nelson, Martin et al., 1998). In going a step further, 
Hayes, Symington et al. (1994) maintain that drawing in elementary school science contributes to children's enjoyment and satisfaction.

Kress, Jewitt, Ogborn and Tsatsarelis (2001) carried out an empirical study of special interest in which they argue that different modes of communication, i.e. different forms of representation, need to be interwoven into the science classroom in order to promote the meaning-making process. Spoken or written language is not enough when communicating science, they say. In line with this, Jakobson and Wickman (manuscript) examined what was mediated when elementary school children observed and rubbed leaves in a science class. Different mediating artefacts were used (magnifiers and crayons) and it was shown that the mediating artefacts, together with the teacher's objectives and interventions, afforded the children to observe the leaves' different aspects and features. The study confirms the findings of Kress, Jewitt et al. (2001), which are that different modes of communication have various consequences for what children are able to learn. Here we expand the analysis to include what children learn when involved in observations and artwork in a science class and in an art class using biological objects (aquarium fish) and a variety of different resources (magnifiers, watercolours, tissue paper and paste, writing and verbal discussions).

\section{Theoretical background}

We use a practical epistemology analysis (PEA) that takes its stance from Dewey and the later works of Wittgenstein and from socio-cultural approaches (Wickman, 2004; Wickman \& Östman, 2002a). Learning is seen as part of the meaning-making process and regarded as active. The unit of analysis in a PEA is similar to that in socio-cultural approaches, which means that we analyse actions as situated in whole activities (e.g. Harré \& Gillette, 1994; Wertsch, 1995).

We view talk as action, starting from Wittgenstein's (1953/1992) language-games, because talking means acting in relation to others (Wickman, 2006). Wittgenstein (1953/1992) argues that language is part of an activity and together with that activity constitutes a language-game. In order to understand the meaning of the words used - including aesthetic judgements - we need to study a particular situation that is itself situated in a language-game (Harré $\&$ Gillett, 1994; Wittgenstein, 1966).

When using a PEA we analyse the interactions in a specific situation and what this means for how the ways of learning influence which route learning takes. This is in accordance with Lave's (1996) notion that learning is continually taking place. Both Rogoff (1990) and Lave (1996) emphasise that learning is a habit and part of a natural rhythm. This means that our experiences are continually being transformed in interactions with the world around us, which is in accordance with Dewey's (1938/1997) principle of continuity. In line with this, observing is not merely a question of perceiving. Instead, previous experiences are reconstructed and transformed in the experience, which then is expanded and deepened (Dewey, 1934/1980). There might be a problem here though, in that learning does not always take the direction demanded by, for example, a teacher (Rogoff, 1990). In this context, PEA makes it possible to follow how interactions in class produce certain meanings and identify where these meanings represent the desired content.

Besides pointing out, that both scientists and artists make observations, Dewey (1925/1958, 1956/1990) also maintains that artwork develops children's observational skills. Observing, whether in a science or an art class, always involves making decisions about what to include and exclude in order to carry the activity forward. Accordingly, what is being distinguished has consequences for the direction that learning takes and hence for what is learned. In deciding the route of our actions, we also need to decide how we feel about them. Such decisions are frequently expressed as aesthetic judgements and are regularly shared and communicated by the participants (Jakobson \& Wickman, 2008; Wickman, 2006). This is in accordance with Dewey's (1934/1980) holistic definition of an aesthetic experience, which embraces cognitive aspects, emotions, values and doings. An experience that makes sense is also, and inevitably, an aesthetic experience.

Although a PEA is related to other methodologies of analysing discourse (e.g. Coulon, 1995; Gee \& Green, 1998; Hutchby \& Wooffitt, 1998), it is particularly developed to analyse meaning-making from a 
first person perspective. The meaning that is made can also be reflected on from a third person perspective, e.g. teachers or researchers, in order to identify the route that learning takes. In line with this, a PEA was used to track the meaning-making process cognitively as well as aesthetically (Jakobson \& Wickman, 2007, 2008; Lidar, Lundqvist, \& Östman, 2006; Wickman, 2004, 2006; Wickman \& Östman, 2002a, b).

In accordance with the theoretical considerations outlined above, in this article we study how different encounters influence what children learn about fish in both a science and an art class. We also examine how aesthetic experience constitutes children's possibilities of participation in the activities.

\section{Methodological approach}

A PEA consists of a number of operational terms (Wickman, 2004; Wickman \& Östman, 2002a). The terms used in the analysis of the empirical material referred to in this article are the relations construed by the children in the science and art classes and the encounters that occurred there. Learning takes place when relations are construed, which in effect means that the participants can proceed with the activity they are involved in. One example of this is Anders and Douglas simultaneously observing a fish with magnifiers and painting the fish (turns 5-6):

Anders: Oh, oh! [in a warning tone] He's really got lots of fins at the rear end.

\section{Douglas: Yes.}

Anders thus construed the relations "really got lots of", "fins" and "at the rear end" to the fish. All these relations construed were both immediate and apparently fully intelligible to Douglas, who agreed. Accordingly, the boys learned something new about fish, as indicated by Anders' interjection of "Oh, oh". But learning can also take an undesired direction in the sense that it is not as fruitful as the intended or expected meaning. This happens when the participants are unable to construe relations in the desired manner, which leads to learning taking another direction or coming to a halt.

Although the term "relation" deals with linguistic meaning-making, the term "encounter" refers to the interactions that take place in a specific situation. In the above excerpt there was not only an encounter between the boys, but also between the boys, the fish and the resources being used, namely, magnifiers and watercolours. In all six settings encounters took place between the children, between the children and the fish and between the children and the different resources. It is possible to analyse these occurring encounters and construed relations with a PEA in order to see what the children learned about fish within the different settings. A study of how these resources mediates meaning, can also be seen to be a study of how certain artefacts with a wide range of possible uses are transformed into purposeful instruments in specific activities (Rabardel, 1995).

To study how aesthetic experiences relate to children's possibilities of participation and learning in the activities, we in line with Wickman (2006) use children's aesthetic judgements as a unit of analysis. Aesthetic judgements can be used to study how children value the different encounters that occur during the lessons. We specifically analysed how the encounters of which aesthetic judgements were a part made students proceed and construe certain relations related to learning and participating in science activities. As a supplement we also mention the moral relations that children construed in relation to the fishes they studied. This might not be considered a content of science proper, but it is an important content of school science: to foster respect for living creatures.

\section{The study settings}

As the aim of the study was to examine what children learned about the qualities of fish when observing them in science and art classes, the first author visited six classes in a city school. In addition to audio-recordings, all of which were later transcribed, 78 photographs of the children's art work were collected. In two of the classes the children were aged 8 (Grade 2) and in one of the classes they were aged 7 (Grade 1).

To what degree students can make relevant, scientific observations is highly dependent on their prior experience. Fish were chosen as study objects because they are familiar objects, which permit children to make observations that would be meaningful 
to them and at the same time relevant considering the science syllabus for these years: learning about the structure of plants and animals. As such, fish as study objects fill the purpose of this study.

The children worked in pairs or small groups during the lessons, which were 15-45 minutes long. Recordings were made of 26 pair or small group conversations by means of a microphone placed on the children's desks and later transcribed. It was difficult to determine what the children were saying at times, because they spoke in very low voices. In addition, some of the children's voices were very similar, which led to some confusion in the transcripts.

Of the six different settings, three had a scientific purpose and the remaining three an artistic one. Moreover, the same resources (with two exceptions) were used in both the art and science classes, i.e. watercolours, tissue paper and paste. In one of the science class settings the children were told to talk about their experiences, whereas in one art class setting the children were asked to write a poem. Throughout the children were encouraged to use magnifiers when observing the fish.

The reason for choosing the unit "Fish" was threefold: the aquarium fish (goldfish of different types) were alive and had different shapes and colours and the teachers could expand the unit to apply to, for example, ecology. After the introduction the children in all six settings were given one fish per pair or small group in a little aquarium with a lid and each child was given a magnifier.

\section{Results}

In this section we first of all look at what the children were afforded to learn about the qualities of fish in the science class by using different resources. Secondly, we demonstrate what happened as a result of observing the fish in the art class, this time using different resources and what this meant for the children's meaning-making. Under the separate subheadings we illustrate how the different resources used afforded the children to make certain observations about the qualities of fish and how language use and art activities appeared to be complementary. The children did not only learn cognitively about fish, however, but also aesthetically. We close by showing how learning aesthetic aspects in relation to what could be considered as a scientific subject content was prominent in all six settings, how learning the aesthetic in art class played a conspicuous part, and what this meant for the direction the learning took.

\section{Learning about fish in science class}

The children participating in the science class were told to paint, sculpt and talk about their findings and to make close observations of the fish with magnifiers. Accordingly, three different settings were staged: talking science, painting and sculpturing. In all three settings the first author began by asking the children to "look very closely at the fish". As the resources being used changed, the instructions naturally differed. The children observing the fish with magnifiers were told to talk about their findings, while the children observing the fish and producing artwork were told to "paint the fish as accurately as you can" and "create a sculpture that is as like the fish as possible". The instructions thus mediated that the children were to observe scientifically relevant qualities and that the artwork should be as authentic as possible.

As the children making sculptures from tissue paper and paste were not used to working with the material the children's teacher showed them how to make a two-dimensional sculpture on drawing-paper first. She also encouraged the children to experiment with the material.

\section{Different resources - different learning consequences}

In all three settings the children frequently construed relations to the qualities of the fish being observed. However, the different resources used afforded the children to discern certain qualities of the fish. Although the children in all the settings made the same discernment, e.g. that the fish had eyes, they also made different choices about what to include in the observation. To illustrate this we present two examples of the children observing the fins of the fish. The first one came from Jens and Eric in the setting "talking science": 
1. Eric: It waves its fins.

2. Researcher: Yeah.

3. Eric: It uses the back fin to steer with.

4. Jens: It waves its dorsal fin like this.

Eric noticed that the fish "waves its fins". He also construed the relation "back fin", meaning that he did not just name the fin but also located it. Eric also stated that the fish used the "back fin" to "steer with", which means that he observed that different fins have different functions. This little chat highlights the immediacy of the experience, and that like Jens and Eric the children frequently construed a lot of relations to the fish being observed in a short space of time. In addition, like Eric the children repeatedly used the correct terminology when communicating what they had discerned, e.g. fin, scale and gill (i.e. gill cover). This could be due to the fact that some of them had aquarium fish at home and that many of the children had been fishing.

Like the boys in turns 1-4, Anders and Douglas, who were painting, distinguished the fins of the fish, although in this encounter aspects other than those discerned by Jens and Eric emerged:

5. Anders: O-h, oh. [in a warning tone] He's really got lots of fins at the rear end.

6. Douglas: Yes.

7. Anders: Like this. Like this. Isn't it Douglas? It was like this [points at his painting].

8. Douglas: Yes, look!

9. Anders: Can you see? One, two, three. Three on each side and then at the rear end and then up there.

In one sentence Anders construed a lot of relations to "he" (i.e. the fish), such as "fins", "really got lots of "and "at the rear end". Anders did not only use the correct terminology, but also observed that the fish had lots of fins, and located them by using the expression "at the rear end". He continued to observe the fish and distinguished that it had "sides" and that there were "three" fins on each side. In addition he construed the relation "up there" to the back of the fish, where he also could see fins. Besides locating the fins he also counted them - although not the "rear" fins as there were a lot of them (turn 5). This information was of importance to Anders because it enabled him to make his painting as authentic as possible. His painting is detailed and includes fins, colour, gills and scales (Figure 1), which indicates that the art activity was continuous with learning about the qualities of the fish. He also labelled the different parts of the fish he painted. Such labelling was unique, however, and only appeared in this setting. This might be due to the fact that elementary school teachers often ask children to write about what they have been drawing in science class as a way of checking what they have learned, particularly as children's pictures are often difficult to decipher.

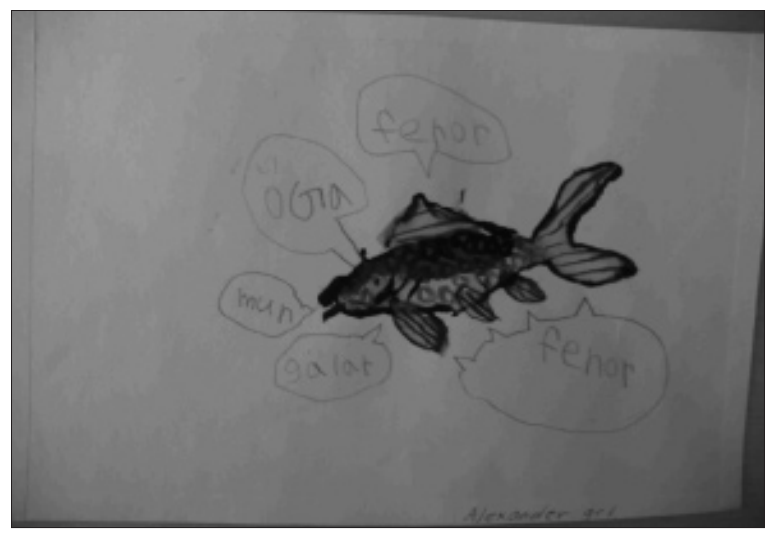

Figure 1 Ander's painting with attached information about the names of the different parts of the fish

Accordingly, the resources used appear to be of importance for what children observe and are therefore of significance in the meaning-making process. Different modes of communication afford children to make certain decisions about what to include and exclude in order to carry the activity forward. When painting the fish it was important to include details that made the artwork authentic. Like Anders and Douglas, the children involved in an art activity had a naturalistic approach, which resulted in them including qualities like fins, colours and patterns in their artworks, and excluding qualities that were of little consequence for authenticity, e.g. the movement of the fish. Eric and Jens, on the other hand (turns 1-4), made discernments that were almost impossible to include in a piece of art, but that were fully possible to include when talking about what was being observed. Like Eric and Jens, the children involved in talking 
science noticed the movement of the fish to a larger extent than those children who took part in the other settings. Lars, for example, observed that the fish "opens its mouth", while Karina observed that the fish "does not blink" and Emma stated that "It's got eyes that move all the time". In this way specific qualities of the fish were overlooked in some of the different settings, while others were observed and noted.

\section{Language and making images}

The children involved in making images frequently excluded details that were hard to paint or sculpture, which indicated that some of the resources constituted a limitation when depicting the fish due to the children's artistic inexperience. However, they continuously communicated their findings linguistically when observing the fish. In addition, the children excluded qualities that were of little or no interest for the authenticity of their artwork, such as function and movement. Moreover, when talking about and observing the fish, the children in all settings frequently compared the qualities of the fish to familiar objects or qualities when trying to make meaning of what they were discerning. Accordingly, prior experiences were reconstructed and transformed in the new encounter, meaning that there was a continuous transformation of factual knowledge. Language and artwork were therefore regarded as complementary in the meaning-making process. An example of this is Rita and Roger, engaged in sculpturing, who observed the scales of the fish:

10. Rita: He's got a skin like a snake, you know!

11. Roger: Yeah.

12. Rita: He's got things like scales. [inaudible]... He's got skin like a snake.

13. Researcher: Okay. What does it look like? Can you explain?

14. Rita: Like this, when you touch it you get hold of a little piece so that you can lift it.

15. Researcher: Okay.

16. Rita: If you hold it that way it might hurt a bit.

17. Researcher: Okay.
Rita construed the relation "skin like a snake" to "he" (the fish), meaning that her prior experiences of snakes were reconstructed and transformed in this encounter. She continued to construe the correct scientific relation of "scales", although she later referred to the fish having "skin like a snake". When asked by the first-named author to describe snakeskin, she said that there was "a little piece so that you can lift it" (turn 14). Rita's use of additional familiar words and comparisons thus enhanced what she was able to learn about fish. Another example came from Eric, who distinguished that the fish "waves its fins", probably comparing the movement to hands that are waving (turn 1). Like Eric and Rita, the children repeatedly compared qualities of the fish to objects they were already familiar with. In that way they linguistically communicated their findings, although the qualities observed were not always included in the artwork. Despite Rita's close observation of the scales they were not included in her sculpture or that created by Roger. Consequently, art and language were complementary in the meaningmaking process and continuous with learning about the qualities of fish.

The children did not talk about all their findings but some of the qualities were only included in their artwork. One example of this is Anders (Figure 1), who did not talk to his classmate Douglas about the scales but nevertheless included them in his painting. It is possible that the artwork took up a lot of the children's time, with the result that they had little or no time to talk about everything they observed. However, the artwork was shown to enhance children's observation skills in that they observed those qualities that were of importance for authenticity (cf. Figure 1).

The children did not just include visible details when observing, painting and sculpturing the fish, but also their own relation to it. Rita, for example, stated that "you get hold of a little piece so that you can lift it", which ended up in a reflection about how to handle fish, i.e. lifting up the piece in "that way might hurt a bit" (turns 14 and 16). This is a question of ethics - you should not hurt the fish by lifting the scales in the wrong direction, meaning that she was concerned for the well-being of the fish. Children's moral considerations should have consequences for their further engagement or disengagement in science. 


\section{Learning about fish in art class}

The children participating in art class were asked to produce a painting, sculpture or write a poem about the fish. Three settings were thus staged: "painting", "sculpturing" and "writing a poem". The first author repeated the instructions about how to write a poem to the children participating in this setting in an attempt to help them understand what they were expected to do. Poetry is not always easy for younger children to write as turned out to be the case here. Many of the poems were written as stories. The children in the other two settings were encouraged to "paint as nice a picture as you can of the fish. As nice as you can - real pieces of art" and to "make a nice model of this fish". In addition, the teacher showed the children how to handle the tissue paper and paste and make a two-dimensional sculpture on drawing-paper. This was done because the children participating in this setting were not very familiar with this particular technique. In these settings the instructions mediated that the children should produce nice paintings and sculptures, meaning that although they were encouraged to use magnifiers when observing the fish there was plenty of scope for free artistic expression.

\section{Different resources - different learning consequences}

In all three settings the children recurrently construed relations to the qualities of the fish being observed. Again the resources used were shown to be of significance for what the children included and excluded in their artwork. The children also exhibited a naturalistic approach when painting and sculpturing, which indicated that observing was a means of distinguishing what was of importance for the authenticity of the artwork being produced. Henric and Morgan, both involved in sculpturing the fish, observed colours, patterns and shapes in their close observations of the fish:

18. Henric: It's golden. It's got black dots and grey stripes and a little orange tuft and then it's orange.

19. Morgan: No, it's got two!

20. Henric: Yes, two.

21. Teacher: What's the thing that moves at the rear end called?

\section{Henric and Morgan in chorus: Fins.}

Henric immediately construed the relation "golden" to the colour of the fish and in addition observed that there were patterns in the form of "black dots" and "grey stripes". He concluded that the fish had "a little orange tuft", which was corrected by Morgan as being two rather than one (turn 19), and that the entire fish was "orange". Furthermore, when asked by the teacher the boys immediately construed the relation "fins" to "the thing that moves at the rear end", thus showing that they were familiar with this part of the body by using the correct terminology. Accordingly, the boys construed a lot of relations to the qualities of the fish in a short space of time. Morgan's sculpture shows the "black dots" and "stripes" as well as the colour of the fish. He also sculptured the fins, observing that the fish had lots of them (Figure 2). Similarly, the children who were involved in sculpturing and painting the fish also construed relations to the qualities of the fish, such as colour, shapes and patterns that were to be included in the resulting artwork. Arthur, painting the fish, observed that "It's got yellow dots", while Emma, involved in sculpturing, noted that "It's got one such stripe...And it's got black up there on the fin, at the very rear end". Hence, sculpturing and painting enhanced the children's observational skills and were continuous with learning about the qualities of the fish.

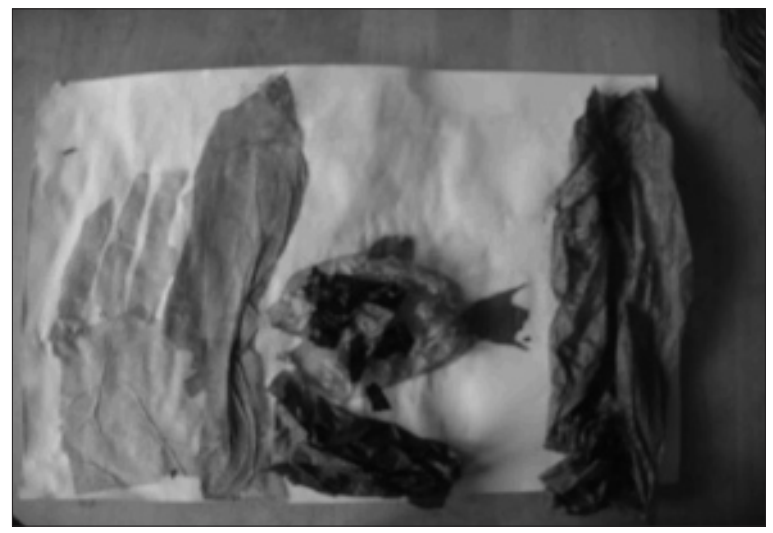

Figure 2 Morgan's sculpture showed lots of details like black dots, stripes, the fins, and the colour of the fish.

The resources used sometimes limited what the children were able to include in their artwork. This was obviously the case in the setting writing poems. 
Although the children observed the fish and construed relations to its qualities, for example, that it was "fat", had "black dots", was "golden" and that "it's got a really big tail", the writing itself constituted an obstacle as to what the children were able to incorporate in their poems. Instead they were anxious about the spelling and how to express themselves in writing. What was most accentuated in this setting was that the children not only learned about the qualities of fish, but also about their own relations to the observed fish. In doing so, the children expressed moral considerations, which mostly embraced feeling sorry for the fish in one way or another. Martin and Erica, for example, were concerned about how the fish would "manage the weekend", in the sense that they were concerned about how to feed the fish so that it would survive the weekend. Amanda, on the other hand, was quite satisfied with the fish living in the little aquarium:

A little fish is swimming and rests its thoughts. Oh, how well it feels. No shark will eat it and it is thinking like this. I feel well, I am not worried about me because I feel that well. Here it is so calm and silent. Here nobody needs to be afraid. The little fish is thinking.

In her poem Amanda construed moral relations of caring for the fish in writing that the fish "feels well" and "nobody needs to be afraid", as well as relations of a philosophical kind, for example, "rests its thoughts" and "the little fish is thinking". Her poem is permeated with confidence and trust about the well-being of the fish, and also with warmth and love. Again this shows how different resources constitute children's choices about what to include when proceeding with the activity they are engaged in. Amanda's reflections in extension are an integral part of learning the aesthetics of science, i.e. about what she finds pleasing or displeasing, and what is beautiful or ugly. Such discernment was shown to occupy the children's time most frequently in both science and art classes.

Accordingly, the resources used are of importance for what children discern and for the meaning-making process. Different resources afford children to make certain decisions about what to include and exclude in their artwork. When sculpturing the fish it was important to include colour and pattern (Figure 2), whereas when writing poems the well-being of the fish was in focus, which ended in moral considerations (cf. Amanda's poem). Such considerations are hard to express in a painting or a sculpture, but can be formulated in writing. Hence, some qualities were disregarded in both settings for the benefit of others.

\section{Language and art}

Like the children participating in the science class, the children who took part in the art class frequently excluded those qualities of the fish that were difficult to sculpt, paint or write about. However, the children communicated their findings in talk, implying that what was excluded in their artwork was sometimes included in their oral communication. When talking to each other and trying to make meaning of what they were observing the children made comparisons to familiar qualities or objects. Accordingly, previous experiences were reconstructed and transformed in the encounter with the fish. One example came from Lisa and Arthur in the painting setting:

23. Lisa: It looks like a moustache above the mouth.

\section{Arthur: Mm}

Lisa construed the relation "moustache" to a quality that she observed above the mouth of the fish. Hence, when trying to make meaning of what she observed, she used words that were already familiar to her. Such comparisons helped the children to communicate their findings and were meaningful to their classmates. Another example came from Henric, who compared the nare to a "tuft" (turn 18). Hence there was a continuous transformation of conceptual, cognitive knowledge.

But the resources used also obstructed what the children were able to include in their artwork, particularly in view of their limited artistic skills. Despite Lisa's and Arthur's close observation of the "moustache" (turns 23-24), it was not included in their paintings. Painting small details, like a moustache, with watercolours might result in the colour floating away and spoiling the painting. On the other hand, as the children frequently talked about what they were discerning and distinguishing, the painting and the talking were complementary, contributed to the scientific meaning-making process and helped the children to continue with the activity.

The reverse also occurred, in that the children included qualities of the fish in their artwork that 
had not been communicated orally. An example of this came from Victor and Klas in the painting setting, who linguistically distinguished the colour of the fish:

25. Victor: What are you supposed to start with?

26. Klas: I don't know. I've started with the little rounded part up there...yellow...yellow as gold.

27. Victor: And a little orange.

28. Klas: Yeah.

When the boys started to talk about how to proceed with the activity, they also began to observe the fish. Klas construed the relation "up there", presumably to the back of the fish, and simultaneously discerned that the back was "the little rounded part up there". He then went on to construe relations to the colour of the fish as "yellow" and extended the observation to a comparison: "yellow as gold". Again, previous experiences were reconstructed and transformed in the new encounter, meaning that there are various nuances of yellow. In addition, Victor noticed that the fish was "a little orange". As the boys proceeded with the activity they stopped talking about the appearance of the fish. But as can be seen in Figure 3, Victor's painting incorporates the shape of the fish as well as its gill covers, fins and nare. He also noticed that the colour of the fish changed. Accordingly, he observed the fish throughout the activity without discussing his findings, and was instead involved in making the painting as authentic as possible. Like Victor, the children engaged in painting and sculpturing displayed a naturalistic approach to their artwork.

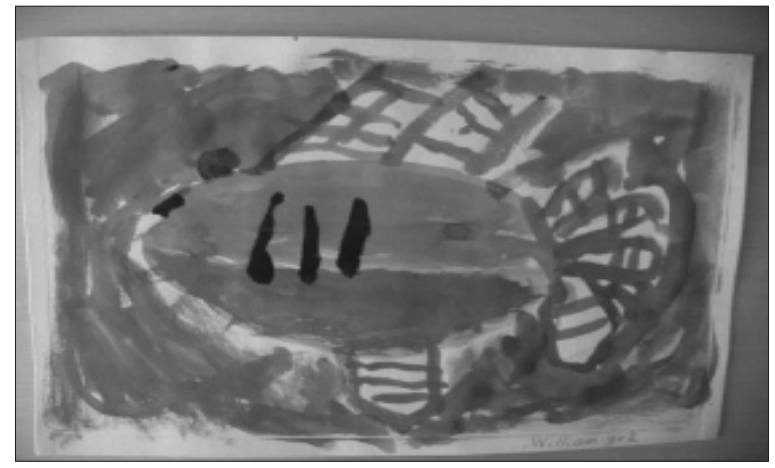

Figure 3 Victor included detailes in his painting (e.g. gill covers, fins, and nares) that he did not talk about.

\section{Learning the aesthetics of science and the aesthetics of art}

In all settings the children learned the aesthetics of science and of art, which could be identified from their use of aesthetic judgements. In order to demonstrate that the use of aesthetic judgements was not casual and infrequent, we present data that shows that the children repeatedly used aesthetic judgements when talking about what they distinguished as part of the activity they were involved in. Typically, a group of children used aesthetic judgements every 1-3 min (Table 1). The aesthetic judgements used with regard to the artwork were related to the authenticity of the fish being painted or sculptured and were scientific in nature. However, the children also expressed their delight about artistic qualities in relation to the artwork being produced. 
Table 1 Frequency of the children's use of aesthetic judgements in relation to the scientific content and to the artwork.

\begin{tabular}{|c|c|c|c|c|c|}
\hline Settings & $\begin{array}{c}\text { Number of groups } \\
\text { in class }\end{array}$ & $\begin{array}{l}\text { Duration of } \\
\text { the lesson }\end{array}$ & $\begin{array}{l}\text { Number of aesthetic } \\
\text { judgements in } \\
\text { relation to the fish }\end{array}$ & $\begin{array}{l}\text { Number of aesthetic } \\
\text { judgements in } \\
\text { relation to the } \\
\text { artwork }\end{array}$ & $\begin{array}{l}\text { Mean time (min) } \\
\text { between aesthetic } \\
\text { judgements }\end{array}$ \\
\hline Talking science & 5 & 15 & 116 & 0 & 0.65 \\
\hline $\begin{array}{c}\text { Painting in science } \\
\text { class }\end{array}$ & 4 & 40 & 27 & 2 & 3.2 \\
\hline $\begin{array}{l}\text { Sculpturing in } \\
\text { science class }\end{array}$ & 5 & 35 & 77 & 43 & 1.46 \\
\hline $\begin{array}{l}\text { Writing a poem in } \\
\text { art class }\end{array}$ & 5 & 30 & 58 & 3 & 2.5 \\
\hline Painting in art class & 3 & 30 & 31 & 27 & 1.55 \\
\hline $\begin{array}{c}\text { Sculpturing in art } \\
\text { class }\end{array}$ & 4 & 45 & 38 & 52 & 2.0 \\
\hline
\end{tabular}

\section{Learning the aesthetics of science}

The children used positive aesthetic judgements when observing the fish, meaning that the aesthetic experience of encountering the fish was pleasant and they enjoyed taking part in the class. One example of this came from Johanna in the setting talking science (aesthetic judgements in bold type in the excerpts):

29. Johanna: Oh! [with wonder] It's really beautiful. It looks like a goldfish, but it's another kind of fish. It looks like glitter.

\section{[ ]}

30. Johanna: They really have a lot, the fins look like scarves through the magnifier... It's glittery.

Johanna was quite overwhelmed when observing the fish with a magnifier, which was shown in her use of positive aesthetic judgements like "Oh!", and "beautiful". At the same time she started to observe the fish more closely and discerned that the fish looked like a "goldfish". She also distinguished that the scales looked like "glitter", with an undertone of positive aesthetics. When Johanna proceeded with the activity she also expressed that when using the magnifier properly, which is a question of how to act in the right way, you could see that the fins look like "scarves". Again her choice of words had a positive aesthetic undertone, meaning that she anticipated what would occur when proceeding with the activity. Johanna concluded by saying that the fish was "glittery". Hence, the aesthetic experience was continuous with cognitive, normative and aesthetic learning about fishes.

When learning cognitively and normatively, i.e. about what to include or exclude in the observation and the artwork and how to act in the science class, the children frequently used positive aesthetic judgements and words with an aesthetic undertone to sort out what was of importance. Throughout the children's aesthetic experiences were shown to carry the activity forward in the right direction. This was also the case with Johanna (turns 29-30), as the learning of the facts, norms and aesthetics of science frequently merged. When discerning that the fish looked "beautiful", she simultaneously distinguished specific qualities of the fish and decided what to include when proceeding with the activity ("looks like a goldfish", "glitter", "scarves"). In order to see the full beauty of the different parts of the fish it was necessary to use a magnifier, i.e. learning the norms of how to act in the right way. Accordingly, the aesthetic judgements expressed were not only emotional, but were continuous in the experience as a whole, meaning that proceeding with the activity in hand and observing more qualities of the fish was worthwhile. This is also a question of children's possibilities of participating in class and their own relation to science. If children recurrently experience that science is part of their own lives, it follows 
that they will experience science as something that concerns them.

Aesthetic judgements were also used in the summing up of the whole experience of encountering the fish. Lukas and Mary, again in the setting talking science, closely observed the tail fin of the fish. The experience led to wonder and excitement, as expressed by Lukas in a positive aesthetic judgement:

31. Mary: Hey look, the rear fins are like this, you know!

32. Lukas: Hey look! It's in three pieces!

33. Mary: Yea-ah, I know.

34. Lukas: Cool.

35. Mary: Mm.

Mary observed that the fish had "rear fins", meaning that she not only named the fins but also located them. Lukas went on to construe the relation "three pieces" to the "rear fin", implying that he discerned that the tail fin was divided into several parts. He summed up the whole experience by using the positive aesthetic judgement "cool" (turn 34). In doing so he communicated that participating in a science class and observing fish was fascinating and exciting and that fins were details to include in the observation. By the aesthetic judgement "cool" he also expressed an anticipation of what further observations might have in store, meaning that it was worthwhile proceeding with the activity. Hence, the aesthetic experience, expressed in aesthetic judgements, was of significance for the direction taken by learning and meaning making.

\section{Learning the aesthetics of art}

The children also construed positive aesthetic judgements in relation to the emerging artwork, meaning that they were pleased with the results. Moreover, their satisfaction was frequently related to the fact that they had succeeded in making the painting or sculpture as authentic as possible. In that way, the scientific content could be said to be at the forefront even though the purpose was artistic. One example of this came from Sebastian and Charles while painting the fish in the art class:

36. Sebastian: I'm painting the fish exactly how it looks.

37. Charles: What did you say?

38. Sebastian: I'm painting the fish exactly how it looks.

39. Charles: Which one do you think is the nicest then?

40. Sebastian: Mine.

41. Charles: Yes, it probably is.

42. Sebastian: You didn't get it looking exact. I used the magnifier and checked.

43. Charles: Mm.

Sebastian was satisfied with his attempt to make the painting of the fish as real as possible, which he expressed in the wording "exactly how it looks" and "painting the fish exactly" (turns 36 and 38). When asked by Charles which of the paintings he thought was the "nicest", there was no doubt that Sebastian regarded his own piece of art as the best (turn 40). Hence, making a "nice" painting of the fish was equal to making an exact copy of it. Sebastian also stated that observing through the magnifier was completely acceptable. Again, this is a question about norms, i.e. how to act in order to proceed with the activity in the right direction, so as to make as an authentic a picture of the fish as possible. It is also a question of what to include in the observation: discerning what belongs to science and what does not. Accordingly, being involved in the art class did not mean leaving out the scientifically relevant qualities of the fish, but interweaving them into the activity.

The children also used aesthetic judgements when referring to artistic qualities, i.e. when including details other than the qualities of the fish in their paintings or sculptures. In those instances the children were anxious about creating a good environment around the fish, in the sense that the relations construed had moral ramifications. One example came from Henric and Morgan when they were sculpturing the fish in the art class: 
44. Henric: Look!...Look at mine [sculpture]!... Look at mine Morgan! It's got seaweed. I'll draw a lot of that.

45. Morgan: How fine it's getting.

46. Henric: Look, it lives, it lives in a coral reef. Isn't that nice!

47. Morgan: Yes.

48. Henric: Mm.

Both Henric and Morgan were satisfied with Henric's sculpture and expressed this in positive aesthetic judgements like "fine" and "nice" relating to "seaweed" and "coral reef". Making a nice looking piece of art was important to the boys, which was also the aim of the lesson. Moral implications were also involved, although were not fully expressed. Henric implicitly said that he wanted the sculptured fish to live in surroundings that were good for it, which indicates that children's aesthetic and moral judgements are closely related (turns 44, 46).

Artistic qualities were also in focus when Amanda read her poem to a classmate, Johannes. Johannes expressed great admiration for what Amanda had written in positive aesthetic judgements: "Wow! [admiring] It's dead cool!" Like Henric's sculpture, Amanda's poem is permeated with moral undertones. It is difficult to say whether Johannes noticed this or just simply liked what Amanda had written, however. Like children's aesthetics, moral considerations reflect the relation to the activity concerned, which have consequences for their engagement or disengagement in activities like art and science in the future. Accordingly, children's aesthetics which at times have moral ramifications are of significance for the route that learning takes and hence for what children can learn.

\section{Summary}

Although the children were involved in observing and producing artwork for two different purposes - one artistic and the other scientific - when talking they frequently construed scientifically relevant relations to the qualities of the fish. To demonstrate this we present data that shows how often qualities were mentioned. On average, a group of children construed cognitive relations to the fish about every ${ }^{1 / 2}-1$ min (Table 2).

\begin{tabular}{|c|c|c|}
\hline Settings & Number of qualities observed & Mean time (min) between qualities observed \\
\hline Talking science & 307 & 0.24 \\
\hline Painting in science class & 197 & 0.8 \\
\hline Sculpturing in science class & 232 & 0.75 \\
\hline Writing a poem & 153 & 0.98 \\
\hline Painting in art class & 139 & 0.65 \\
\hline Sculpturing in art class & 203 & 0.9 \\
\hline
\end{tabular}

Table 2 The frequency of qualities observed and orally expressed in each setting

The different resources used afforded the children to make certain observations of the qualities of the fish (summarised in Table 3). When involved in art activities, the children largely included qualities that were of significance for authenticity, while the children engaged in talking science included the functions and movements of different parts of the creature's body (e.g. turns 1-4). However, some qualities proved to be difficult to include in the artwork as a result of the children's lack of artistic skills. The resources used therefore constituted something of a limitation for what the children were able to incorporate in the artwork (turns 23-24). 


\begin{tabular}{|c|c|c|c|c|}
\hline Settings & Tasks & Tools & $\begin{array}{l}\text { Most important } \\
\text { relations construed }\end{array}$ & $\begin{array}{l}\text { Corresponding } \\
\text { excerpts }\end{array}$ \\
\hline Talking science & observation & magnifiers & movement, function & $1-4$ \\
\hline $\begin{array}{c}\text { Painting in science } \\
\text { class }\end{array}$ & $\begin{array}{c}\text { observation, } \\
\text { authentic painting }\end{array}$ & $\begin{array}{c}\text { magnifiers, } \\
\text { watercolours }\end{array}$ & qualities & $5-9$ \\
\hline $\begin{array}{l}\text { Sculpturing in } \\
\text { science class }\end{array}$ & $\begin{array}{c}\text { observation, } \\
\text { authentic } \\
\text { sculpture }\end{array}$ & $\begin{array}{l}\text { magnifiers, tissue } \\
\text { paper and paste }\end{array}$ & qualities & $10-17$ \\
\hline $\begin{array}{l}\text { Writing a poem in } \\
\text { art class }\end{array}$ & $\begin{array}{c}\text { observation, } \\
\text { writing about the } \\
\text { fish }\end{array}$ & $\begin{array}{l}\text { magnifiers, paper } \\
\text { and pencil }\end{array}$ & moral considerations & Amanda's poem \\
\hline $\begin{array}{l}\text { Painting in art } \\
\text { class }\end{array}$ & $\begin{array}{l}\text { observation, } \\
\text { a nice picture }\end{array}$ & $\begin{array}{l}\text { magnifiers, } \\
\text { watercolours }\end{array}$ & qualities & $23-24,25-28$ \\
\hline $\begin{array}{l}\text { Sculpturing in art } \\
\text { class }\end{array}$ & $\begin{array}{c}\text { observation, a nice } \\
\text { model }\end{array}$ & $\begin{array}{l}\text { magnifiers, tissue } \\
\text { paper and paste }\end{array}$ & qualities & $18-22$ \\
\hline
\end{tabular}

Table 3 A summary of the most important relations construed by the children in each setting.

When talking to each other the children involved in art activities communicated what they had distinguished, although this did not always result in their discernments being included in their artworks. Talking was therefore complementary to the artistic activity and enabled the children to make meaning and communicate their findings (turns 10-17, 2324). The reverse was also the case, thus implying that the children included qualities of fish in their artwork even though they did not verbally communicate what they had discerned (Figure 1). Nevertheless, throughout the art activities the children observed the fish and were involved in making their paintings and sculptures as authentic as possible. In that way, painting and sculpturing both promoted and were continuous with the children's learning about the qualities of fish.

The children also learned about their own relations to the fish being observed, which was shown in their use of positive aesthetic judgements (Table 1 ) and through their moral considerations (turn 16, Amanda's poem and turns 44-48). Moral considerations were most accentuated in the setting "writing poems" and dealt with the wellbeing of the fish. With regard to the number of positive aesthetic judgements, observing the fish seemed to be a pleasant experience for the children. Aesthetic learning was shown to embrace both cognitive learning as well as learning norms about how to act and what to exclude and include in order to carry the activity forward (turns 29-30). Positive aesthetic judgements were also used in summing up the experience of encountering the fish (turn 34). In addition, the children's aesthetics were shown to have moral ramifications (Amanda's poem and turns 44-48). This rich meaning of children's aesthetic experiences constitutes an indication of the route that children's learning takes, and is of importance for children's possibility to participate in a science class. In a long term view, children's aesthetic experiences should be essential to their future scientific engagement or disengagement.

In addition, the children were often satisfied with their artworks, which was indicated by the positive aesthetic judgements used. Their satisfaction of the artwork was mostly concerned with its authenticity, regardless of the aim of the activity (turns 36-43) or the artistic qualities expressed in the art class (turns 44-48). Accordingly, art - independent of the purpose - was shown to be continuous with cognitive and normative scientific learning as well as aesthetic learning.

\section{Discussion}

As has been shown in this article, science and art are not essentially different but merge when children are involved in observations and art activities in class. Notwithstanding the fact that the aims differed and the resources used varied, the children frequently construed a lot of naturalistic relations to the fish. Hence, they continuously learned scientifically about the fish in all the settings, which indicates that art - at least to children - is not just a question of private 
emotions as argued by Gardner (1971). When learning cognitively about the object being observed, art in science education cannot only be viewed as a motivating power but must also be seen as a means. These elementary school children do not differentiate between science and art, but instead have a naturalistic approach in relation to the artwork being created, irrespective of whether they are involved in a science or an art class. This is in agreement with the observations by Kindler, Darras \& Kuo (2000), viz. that young children have already established attitudes towards art. Accordingly, as has been pointed out by several scholars (e.g. Fischer, 1999; Root-Bernstein, 1996; Vickers, 1988), at least for this age group science and art can be compatible and possible to combine, which should be of interest to teachers.

However, the resources chosen proved to be of importance for what the children discerned and hence for what they included in their observations and artwork. Accordingly, different modes of communication bring out certain aspects, while others are disregarded, which in turn has consequences for the meaning-making process. In terms of enhancing children's learning, teachers should be careful in their choice of which resources to use and relate them to the aim of the lesson in question, because each resource embraces both limitations and potential with regard to the meaning-making process, as pointed out by Kress, Jewitt et al. (2001) and Jakobson and Wickman (manuscript).

In addition, children's familiarity with the material used was of significance for what they were able to include in their artwork, meaning that some qualities of the fish were left out while others were incorporated. Sculpturing using tissue paper and paste, for instance, proved to be both sticky and clumsy, which meant that the children were unable to include microscopic forms like scales in their creations. Likewise, writing poetry was difficult for the children, which consequently constituted a limitation for what they were able to include in their writings. The children's lack of artistic skills thereby constrained what they were able to include in their artwork, although they frequently in talk communicated scientifically relevant things about the qualities of fish. On the other hand, resources that were familiar to the children promoted the learning of science. Hence, art in the science class and science in the art class enhances what children are able to learn cognitively if they are familiar with the resources being used, which should be noticed by teachers.

Throughout the settings the children were involved in observing the fish using magnifiers. Accordingly, observation was shown to be important in both the science and the art class. In accordance with this, the children were anxious to make their artwork as authentic as possible. In that way the art activity enhanced the children's observational skills; something that has also been pointed out by several scholars (e.g. Gainer \& Child, 1986; Hayes, Symington et al, 1994; Laverne Nelson et al., 1998). This is in line with Dewey (1925/1958; 1899/1990), and Watts (2001), who argue that observing is common to both art and science. Accordingly, the children continuously distinguished relevant qualities of the fish when talking and creating their artwork. Further studies are needed regarding what art can contribute to science beyond this specific setting where children have a naturlistic stance to art.

Moreover, in all the settings the children frequently used the correct terminology when communicating what they had distinguished. They also compared the qualities of the fish to familiar objects and qualities. The comparisons were both immediate and fully intelligible to their classmates. This shows how words acquire their meaning in specific interactions, which is in accordance with Wittgenstein's (1953/1992) language-games. Besides, in the meaning-making process language use and art activities were shown to be complementary. Hence, what is learned depends on the simultaneous use of the different modes of communication and resources used. Accordingly, a teaching sequence should include various modes of communication and a variety of resources in order to facilitate children's learning as outlined by Kress, Jewitt et al. (2001).

Furthermore, the children learned about their own relation to the activity they were involved in. Learning the aesthetics of science, which also includes moral ramifications, was shown to take up a lot of the children's time. In all the settings the children continuously expressed themselves in positive aesthetic judgements. Such judgements were used when learning what to include and what belonged to the scientific discourse, i.e. norms about how to 
proceed with the activity. Aesthetic judgements were also used when communicating that observing the fish was pleasurable and that pursuing the activity to its fulfilment was worthwhile. Although learning the aesthetics of science has sometimes been separated from cognitive learning (e.g. Novak, 2002; Posner, Strike et al., 1982; Strike \& Posner, 1992), the children's aesthetic experiences were shown to be rich in meaning and significant for the direction of their learning, which should be of significance to teachers to acknowledge. In a long term perspective children's abilities to participate in science activities in school have consequences for their future engagement in science and art. Accordingly, the results presented here show that aesthetics do not only relate to art, but also relate to science and the entire experience of learning and meaning-making. In this way our results largely concur with those of other researchers (e.g. Bloom 1992a, b; Flannery, 1991; Jakobson \& Wickman, 2008; Wickman, 2006)

The children's aesthetics embraced their satisfaction with the artwork being produced. Because the children enjoyed creating their artwork they frequently construed positive aesthetic relations concerning the authenticity of the fish being painted or sculptured. Hence, the children can be said to have related to science and art in the sense that the two activities merged. The children's satisfaction with their artwork is important in this context, because the pleasure of producing a nice piece of art may also have a positive effect on their future learning in science (cf. Hayes, Symington et al. 1994). If children experience constant disappointment with their artwork, it may result in them the hesitating to participate in similar activities in the future. In this way, through aesthetic experience, children can be said to have been learning not only cognitively about fish, but also aesthetically.

To conclude, different modes of communication in a specific activity with a certain purpose have various consequences for what children learn. What children learn is situated and dependent on the specific encounters that occur. Hence, different resources bring different qualities to the fore, while others are disregarded. In this case the children continuously learned about fish independent of the setting they were participating in and independent of the purpose of the activity. Moreover, as the art activities proved to be enjoyable, they have the potential to humanise and enliven the learning of science. Accordingly, we should stop asking whether art is promoting science learning or not and instead inquire into the different ways that different art activities can contribute to students' scientific meaning making. 


\section{REFERENCES}

Bloom, J. D. (1992a). Contexts of meaning and conceptual integration: How children understand and learn. In R. A. Duschl \& R. J. Hamilton (Eds.), Philosophy of science, cognitive psychology and educational theory and practice. (pp. 177-194). Albany: State University of New York Press.

Bloom, J. D. (1992b). The development of scientific knowledge in elementary school children: A context of meaning perspective. Science Education, 76, 399-413.

Coulon, A. (1995). Ethnomethodology. Thousand Oaks, CA: Sage.

Dewey, J. (1899/1990). The school and society. The child and the curriculum. London: The University of Chicago Press Ltd

Dewey, J. (1925/1958). Experience and nature. New York: Dover.

Dewey, J. (1934/1980). Art as experience. New York: Perigee Books.

Dewey, J. (1938/1997). Experience \& education. New York: Touchstone.

Fischer, E. P. (1999). Beauty and the beast. The aesthetic moment in science. New York: Plenum Publishing Corporation.

Flannery, M. C. (1991). Science and aesthetics: A partnership for science education. Science Education, 75(5), 577-593.

Gainer, R. S., \& Child, J. S. (1986). Scientific illustration for the elementary school. Art Education, November 1986, 19-22.

Gardner, H. (1971). Problem-solving in the arts and sciences. Journal of Aesthetic Education, 5(1), 93-113.

Gee, J. P., \& Green, J. L. (1998). Discourse analysis, learning, and social practice: A methodological study. Review of Research in Education, 23, 119-169.

Goodman, N. (1969). Languages of art. An approach to a theory of symbols. London: Oxford University Press.

Harré, R., \& Gillett, G. (1994). The discursive mind. London: Sage Publications, Inc.

Hayes, D., Symington, D., \& Martin, M. (1994). Drawing during science activity in the primary school. International Journal of Science Education, 16(3), 265-277.

Hutchby, I., \& Wooffitt, R. (1998). Conversation analysis: Principles, practices and applications. Cambridge, UK: Polity Press.

Jakobson, B., \& Wickman, P.-O. (2007). Transformation through language use: Children's spontaneous metaphors in elementary school science. Science \& Education, 16, 267-289.

Jakobson, B., \& Wickman, P.-O. (2008). The roles of aesthetic experience in elementary school science. Research in Science Education, 38, 45-65.

Jakobson, B., \& Wickman, P-O. (manuscript). What difference does art make in science? A comparative study of elementary school children. Unpublished manuscript.

Kindler, A. M., Darras, B., \& Kuo, A. C. S. (2000). When a culture takes a trip: evidence of heritage and enculturation in early conceptions of art. Journal of Art and Design Education, 19, 44-53.

Kress, G., Jewitt, C., Ogborn, J., \& Tsatsarelis, C. (2001). Multimodal teaching and learning. The rhetorics of the science classroom. London: Continuum.

Lave, J. (1996). The practice of learning. In S. Chaiklin, \& J. Lave (Eds.), Understanding practice: Perspectives on activity and context. (pp. 3-32). Cambridge, UK: Cambridge University Press.

Laverne Nelson, P. L., Martin, S. S., \& Baldwin, V. G. (1998). Drawing skills and science concepts in young children: A study of relationships. Studies in Art Education, 39, 262-269.

Lidar, M., Lundqvist, E., \& Östman, L. (2006). Teaching and learning in the science classroom: The interplay between teachers' epistemological moves and students' practical epistemology. Science Education, 90(1), 148-163. 
Novak, J. D. (2002). Meaningful learning: The essential factor for conceptual change in limited or inappropriate propositional hierarchies leading to empowerment of learners. Science Education, 86, 548-571.

Posner, G. J., Strike, K. A., Hewson, P. W., \& Gertzog, W. A. (1982). Accomodation of a scientific conception: Toward a theory of conceptual change. Science Education, 66, 211-227.

Rabardel, P. (1995). Les hommes \& les technologies. Approche cognitive des instruments contemporains. Paris: Armand Colin.

Rogoff, B. (1990). Apprenticeship in thinking: Cognitive development in social context. Oxford: Oxford University Press.

Root-Bernstein, R. S. (1991). Teaching abstracting in an integrated art and science curriculum. Roeper Review, $13,85-90$.

Root-Bernstein, R. S. (1996). The sciences and arts share a common creative aesthetic. In A. I. Tauber (Ed.), The elusive synthesis: Aesthetics and science (pp. 49-82). Dordrecht: Kluwer Academic Publishers.

Strike, K. A., \& Posner, G. J. (1992). A revisionist theory of conceptual change. In R. A. Duschl, \& R. J. Hamilton (Eds.), Philosophy of science, cognitive psychology and educational theory and practice. (pp. 147176). Albany: State University of New York Press.

Watts, M. (2001). Science and poetry: Passion v. prescription in school science? International Journal of Science Education, 23(2), 197-208.

Weigand, H. (1985). From science into art. Art Education, November 1985, 18-21.

Weisskopf, V. F. (1979). Art and science. In Aesthetics and science. Proceedings of the International Symposium in Honor of Robert R. Wilson, April 27 1979. (pp. 99-109). Batavia, Illinois: Fermi National Accelerator Laboratory.

Wertsch, J. V. (1995). The need for action in sociocultural research. Cambridge, UK: Cambridge University Press.

Vickers, G. (1988). Rationality and intuition. In J. Wechsler (Ed.), On aesthetics in science (pp. 143-164). Cambridge: Birkhäuser Boston Inc.

Wickman, P.-O. (2004). The practical epistemologies of the classroom: A study of laboratory work. Science Education, 88(3), 325-344.

Wickman, P.-O. (2006). Aesthetic experience in science education: Learning and meaning-making as situated talk and action. Mahwah, New Jersey: Lawrence Erlbaum Associates.

Wickman, P.-O., \& Östman, L. (2002a). Learning as discourse change: A sociocultural mechanism. Science Education, 86(5), 1-23.

Wickman, P.-O., \& Östman, L. (2002b). Induction as an empirical problem: How students generalize during practical work. International Journal of Science Education, 24(5), 465-486.

Wittgenstein, L. (1953/1992). Philosophical investigations ( $2^{\text {nd }}$ ed.). Oxford: Blackwell.

Wittgenstein, L. (1966). Lectures and conversations on aesthetics, psychology and religious belief. Oxford: Blackwell. 